\title{
MENGURANGI PERILAKU STEREOTYPE MENJILAT TANGAN PADA SISWA AUTIS MELALUI TEKNIK AVERSI
}

\author{
Damri $^{1}$, Irdamurni $^{2}$, Zulmiyetri $^{3}$, Johandri Taufan $^{4}$, NiningAfrianti $^{5}$ \\ ${ }^{1234}$ Universitas Negeri Padang, Indonesia \\ Email: damrirjm@fip.unp.ac.id
}

\section{INFORMASI ARTIKEL}

Terkirim 02 Agustus 2018

Revisi 25 September 2018

Diterima 26 September 2018

\section{Katakunci:}

Autisme, Strereotype,

Teknik Aversi

\begin{abstract}
ABSTRAK
Penerapan teknik aversi pada siswa autisme yang berperilaku stereotype yang suka menjilat tangannya. Metoda yang digunakan eksperimen single subject research (SSR), dengan desain A-B-A. Data dianalisis menggunakan visual grafik mulai dari melakukan analisis dalam kondisi dan antar kondisi. Target behavior diperoleh hasil penghentian prilaku menjilat tangannya. Dari tindakan dan usaha yang dilakukan selama lima kali pertemuan terutama pada kondisi baseline $\left(\mathrm{A}_{1}\right)$ ternyata prilaku tersebut dominan dilakukannya $80 \%$. Selanjutnya setelah dilakukan intervensi (B) selama sepuluh kali pertemuan dengan menggunakan teknik aversi/ prompting terletak pada rentang $10 \%$. Dan pada kondisi baseline $\left(\mathrm{A}_{2}\right)$ lima kali pertemuan tanpa diberikan perlakuan, hasil persentase terletak pada $20 \%$. Kecenderungan arah, kecenderungan stabilitas, kecenderungan jejak data, dan perubahan level menurun secara positif, serta persentase overlap pada analisis antar kondisi. Semakin kecil persentase overlap, semakin kuat pengaruh intervensi terhadap perubahan perilaku.
\end{abstract}

\section{Pendahuluan}

Anak autisme sering mengalami hambatan perkembangan dalam berbagai hal, terutama perkembangan otak, berkomunikasi, berinteraksi sosial dan emosi, gangguan sensori serta pola bermainnya yang sering tenggelam dalam dunianya sendiri yang diekspresikan melalui minat dan perilaku yang berulang-ulang. Hal lain yang tampak dari prilakunya bila diajak bermain selalu menjauh dan mengalami gangguan sensori yang dapat dilihat dalam aktivitas sehari-hari. Beberapa perbedaan perilaku nyata dan mencolok dengan siswa siswa normal. Disamping itu siswa autisme memiliki perilaku yang berlebihan (excessive) dan perilaku yang berkekurangan (deficient).Kondisi tersebut muncul sesuai dengan perkembangan perilaku anak-anak usianya

Hasil asesemen yang di peroleh dari Pusat Layanan Autis Padang terhadap subjek, bahwa kemampuan dasar siswa autisme bisa berkembang secara bertahap menuju normal, baik fisik, sosial, komunikasi, maupun kognitif/ pra akademik meskipun belum optimal. Keterlambatan tersebut dominan disebabkan oleh faktor keluarga dan lingkungannya, pada hal berbagai potensi yang mereka miliki masih dapat dikembangkan terutama melalui pembelajaran secara khusus dan intensif dengan menggunakan aneka teknik

Untuk memastikan kondisi peneliti mengamati, dan mewawancarai guru serta melakukan asesemen terhadap prilaku subjek terutama saat proses pembelajaran di kelas dan bermain di luar ruangan kelas saat sedirian pada jam istirahat.Didapatkan memang benar prilaku menjilat telapak tangan sambil memainkan air liurnya yang ada ditelapak tangan dan kakinya sehingga disela sela jemarinya terdapat kutu air. Menjilat telapak tangan merupakan perbuatan jorok, kotor apalagi tangannya dalam kondisi tidak bersih. jika dibiarkan terus bisa memicu datangnya ganguan kesehatan dan konsentrasi apalagi saat belajar. Guru mengajar merasa risih dengan perilaku ini, karenadapat mengalihkan perhatian siswa lain. Prilaku ini harus segera dihentikan oleh guru karena tidak hanya berdampak terhadap prestasi belajarya tetapi juga berdampak pada kesehatannya.

Setiap autisme ini berbeda-beda steriotipenya. Oleh karena itu penanganan yang diberikan pada masing-masingnya juga tidak sama. Satu sisi mereka mengalami kesulitan dalam kontak mata dengan orang lain, agresif, menyakiti diri sendiri, tantrum,self stimulation serta terpukau terhadap benda yang berputar atau bergerak. Pada sisi lain banyak ditunjukkan dengan perilaku stereotype yang lain salah satuya menjilat telapak tangan dan memainkan air liurnya secara berulang- 
ulang. Guru megakui berbagai upaya telah dilakukan untuk menghentikan perilaku tersebut. mulai dari memperlihatkan video tentang akibat buruk dari kebiasaan tersebut, menegur sampai dengan memberikan hukuman (punishment) dengan memukul tangannya namun hasilya belum merubah kebiasaannya, bisa berheti tetapi sesaat saja namun secara diam- diam siswa tersebut terus mengulanginya.

Untuk mengurangi prilaku strereotype ini, maka perlu ditemukan cara yang dapat membantu salah satunya adalah dengan menggunakan teknik aversi. Selain itu menurut Hadi (2005) bahwa teknik aversi ini telah digunakan secara luas untuk mengurangi bahkan menghilangkan gangguan perilaku yang spesifik termasuk prilaku diatas, dengan melibatkan pengasosiasian tingkah laku simtomatik dengan suatu stimulus yang menyakitkan atau tidak menyenangkan sampai tingkah laku yang tidak diinginkan terhambat kemunculannya.

Perilaku stereotype pada siswa perlu dihilangkan atau dikurangi dengan tujuan supaya siswa lebih fokus dalam proses pembelajaran dan tangan siswa terhindar dari penyakit kulit. Mengurangi perilaku stereotype pada siswa melalui teknik aversi ini diharapkan akan berkurang. Sehingga nantinya ketika dalam proses pembelajaran dan bermain siswa tidak sering melakukan perilaku stereotype.

\section{Metode}

Penelitian ini dilaksanakan dengan menggunakan metode SSR Jenis penelitian ini adalah eksperimen dalam bentuk Single Subject Research. Dengan menggunakan desain A-B-A. Dengan alasan subjek penelitian ini hanya seorang siswa (tunggal ). Menurut Sunanto, J (2005) menyarankan kalau subjek hanya seorang anak, maka dapat digunakan Single Subject Research. Eksperimen merupakan penelitian yang dilakukan untuk mengetahui ada tidaknya akibat dari yang dikenalkan pada subjek yang diteliti.sekaligus mengukur pengaruh suatu atau beberapa variabel terhadap variabel lain (Nana Syaodih, 2007).

Data yang diperoleh dianalisis dengan visual data grafik (Visual Analysis of Grafik Data). Hasil penelitian ini menunjukkan pada kondisi baseline $\left(\mathrm{A}_{1}\right)$ lima kali pertemuan, hasil persentase terletak pada rentang $80 \%$. Pada kondisi intervensi (B) sepuluh kali pertemuan melalui penggunaan teknik aversi dengan prompting terletak pada rentang $10 \%$. Dan pada kondisi baseline $\left(\mathrm{A}_{2}\right)$ lima kali pertemuan tanpa diberikan perlakuan, hasil persentase terletak pada $20 \%$. Kecenderungan arah, kecenderungan stabilitas, kecenderungan jejak data, dan perubahan level menurun secara positif, serta persentase overlap pada analisis antar kondisi. Semakin kecil persentase overlap, semakin kuat pengaruh intervensi terhadap perubahan perilaku. Sehingga dapat diambil kesimpulan bahwa teknik aversi dapat mengurangi perilaku stereotype pada subjek.

\section{Hasil Penelitian \\ A. Deskripsi Data}

Sesuai dengan tujuan penelitian yaitu untuk mengurangi perilaku stereotype siswa autisme melalui modifikasi perilaku. Penelitian ini dilaksanakan dengan menggunakan metode SSR (single subject research). Penelitian ini menggunakan desain A-B-A. Kemudian data yang diperoleh dianalisis dengan menggunakan analisis visual data grafik (Visual Analysis of Grafik Data). Adapun data yang diperoleh dari hasil penelitian dapat dilihat sebagai berikut:

\section{Kondisi Baseline (A1)}

Data baseline $\mathrm{A}_{1}$ diperoleh melalui pengamatan terhadap perilaku stereotype siswa autisme.Baseline $\mathrm{A}_{1}$ dilakukan sebanyak lima kali. Pengamatan dilakukan setiap hari di sekolah. Jumlah perilaku stereotype pada siswa autisme yang muncul akan ditally ke dalam format observasi yang telah disediakan dalam waktu 30 menit. Adapun data dalam kondisi baseline diperoleh sebagai berikut: diketahui bahwa dalam lima kalipengamatan selama 30 menit terhadap perilaku stereotype, terlihat bahwa dalam pengamatan pertama20 kali, pengamatan kedua sebanyak $21 \mathrm{kali}$, pengamatan ketiga sebanyak 24 kali, pengamatan keempat sebanyak 24 kali, pengamatan kelima sebanyak 24 kali.

\section{Kondisi Intervensi (B)}

Pada kondisi intervensi peneliti melaksanakan sebanyak 10 kali pertemuan. Intervensi yang dilakukan peneliti adalah dengan memberikan suatu perlakuan pada siswa melalui teknik aversi dengan memberikan prompting (brucea javanica).Pada pemberian intervensitelapak tangan siswa dioleskan brucea javanica yang sudah dihaluskan. Pada pengamatan ini peneliti masuk kelas sebagai guru yang mengajar dan menemani siswa saat jam istirahat, peneliti berusaha untuk menciptakan suasana yang menyenangkan bersama siswa. Peneliti menghentikan pengamatan karena yang diperoleh dari pertemuan ke-12 sampai ke-15 sudah menunjukkan kestabilan yaitu perilaku stereotype siswa autisme sudah berkurang melalui teknik aversi.

\section{Kondisi baseline A2}

Pada kondisi baseline kedua ini peneliti kembali mengamati perilaku stereotype siswa dan tidak diberikan intervensi atau tidak diberikan perlakuan. Pengamatan pada baseline kedua ini dilakukan selama lima hari Peneliti 
menghentikan pengamatan karena data yang diperoleh menunjukkan kestabilan yaitu dari hari ke- 17 sampai terakhir pengamatan terhadap perilaku stereotype.

\section{B. Analisis Data}

\section{Analisis Dalam Kondisi}

Penelitian ini dilkukan sebanyak 20 kali pertemuan dimana pada $A_{1}$ sebelum intervensi dilakukan pengamatan sebanyak 5 kali pertemuan, pada saat B (intervensi) dilakukan sebanyak 10 kali pertemuan, dan setelah tidak lagi diberi intervensi pada $\mathrm{A}_{2}$ pengamatan dilakukan sebanyak 5 kali pertemuan. Analisis dalam kondisi pada penelitian ini adalah menganalisis perubahan data yang ada pada grafik dalam masing-masing kondisi. Kondisi yang akan dianalisis yaitu kondisi baseline $\left(\mathrm{A}_{1}\right)$, intervensi $(\mathrm{B})$, dan basline $\left(\mathrm{A}_{2}\right)$. Komponen analisis dalam kondisi ini adalah

a. Menentukan panjang kondisi

Panjang kondisi merupakan gambaran dari lamanya waktu pengamatan yang dilakukan pada masing-masing kondisi. Pada penelitian ini pengamatan pada kondisi baseline $\left(\mathrm{A}_{1}\right)$ dilaksanakan sebanyak 5 kali pertemuan. Kondisi intervensi (B) pada penelitian ini, dilaksanakan sebanyak 10 kali pertemuan, pada kondisi baseline $\left(\mathrm{A}_{2}\right)$ dilaksanakan sebanyak 5 kali pertemuan.

\section{b. Menentukan Estimasi Kecendrungan Arah}

Dalam menentukan arah kecendrungan dengan menggunakan metode belah dua(split middle). Berdasarkan data yang diperoleh menunjukkandata yang bervariasi sehingga metode yang dipilih untuk menentukan arah kecendrungan data adalah metode split middle.

Diketahui bahwa pada kondisi baseline $\left(\mathrm{A}_{1}\right)$ menunjukkan data meningkat, pada kondisi intervensi $(\mathrm{B})$ yang menunjukkan arah kecendrungan data menurun, dan pada kondisi baselin $\left(\mathrm{A}_{2}\right)$ juga menunjukkan arah kecendrungan data menurun.

c. Kecenderungan Stabilitas

Menentukan kecenderungan stabilitas pada kondisi $\mathrm{A}_{1}, \mathrm{~B}, \mathrm{~A}_{2}$ digunakan sebuah kriteria stabilitas yang telah ditetapkan. Untuk menentukan kecenderungan stabilitas digunakan kriteria stabilitas $15 \%$. Kemudian dilanjutkan dengan menghitung mean level, batas atas, batas bawah, dan presentase stabilitas. Didapatkan hasil penelitian pada kondisi baseline $\left(\mathrm{A}_{1}\right) 80 \%$, pada kondisi intervensi $(\mathrm{B})$ mendapatkan hasil $10 \%$, dan pada kondisi baseline $\left(\mathrm{A}_{2}\right)$ adalah $20 \%$.

\section{d. Kecenderungan Jejak Data}

Pada data baseline sebelum diberikan intervensi (A1), pada hari pertama sampai pada hari ke tujuh perilaku stereotype (menjilat telapak tangan) siswa autismex yaitu (20, 21, 24, 24, 24,). Hal ini menjelaskan bahwa kecendrungan jejak data pada kondisi A1 adalah cukup tinggi.

Pada kondisi intervensi (B) hari keenam sampai hari ke limabelas perilaku stereotype (menjilat telapak tangan) siswa autisme $\mathrm{X}$ menurun menjadi $(16,14,21,15,12,10,8,7,7,7)$. Hal ini menunjukkan bahwa kencendrungan jejak data pada kondisi intervensi adalah menurun.

Pada data baseline tanpa diberikan perlakuan (A2) yaitu dari pengamatan hari keenam belas sampai hari keduapuluh, dari hari kehari perilaku stereotype (menjilat telapak tangan) siswa autisme $\mathrm{X}$ terlihat mengalami penurunan yaitu $(7,6,5,5,5)$. Pengamatan dihentikan karena dirasa sudah stabil.

e. Menentukan Level Stabilitas dan Rentang

Untuk menentukan level stabilitas dan rentang, maka dapat ditentukan dengan melihat data pada setiap kondisi, dapat dilihat bahwa 24 adalah skor tertinggidan 20 adalah skor terendah pada kondisi baseline (A1). Sedangkan pada kondisi intervensi (B) skor tertinggi adalah 21 dan skor terendah yang diperoleh adalah 7, pada kondisi baseline kedua (A2)7 adalah skor yang tertinggi dan 5 adalah skor yang terendah.

\section{f. Level Perubahan}

Untuk menentukan level perubahan data dalam suatu kondisi. Dapat dipaparkan bahwa level perubahan sebagai berikut:

1) Level perubahan pada kondisi baseline (A1)

a) Data awal $=20$ dan data akhir $=24$

b) Kurangi data kecil dengan data besar20 - $24=-4$

c) 4

2) Level perubahan pada kondisi intervensi (B)

a) Data besar $=21$ dan data yang kecil $=7$

b) Kurangi data besar dengan data kecil $21-7=14$

c) $14(+)$ jadi menunjukkan arahnya membaik.

3) Level perubahan pada kondisi baseline (A2)

a) Data besar $=7$ dan data yang kecil $=5$ 
b) Kurangi data besar dengan data kecil $7-5=2$

c) 2 (+) jadi menunjukkan arah membaik.

Dari hasil analisis visual di atas dapat disimpulkan bahwa metode teknik aversi dapat mengurangi perilaku stereotype siswa autisme $\mathrm{x}$

\section{Analisis Antar Kondisi}

Dari hasil yang telah dilakukan pada penelitian ini yaitu pada sesi baseline $\left(\mathrm{A}_{1}\right)$, intervensi $(\mathrm{B})$, dan baseline $\left(\mathrm{A}_{2}\right)$ dapat dilihat perbandingan tiga bagian itu sebagai berikut:

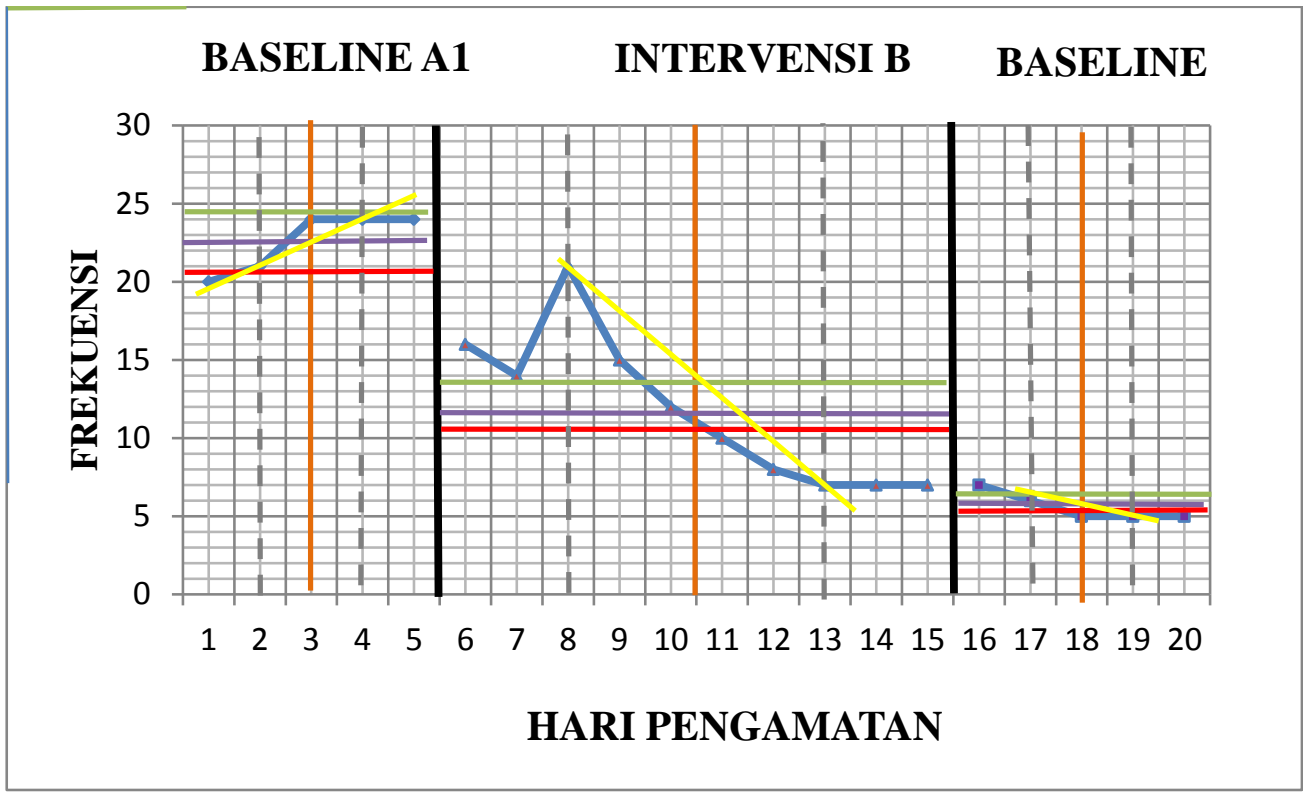

\section{Grafik. Analisis antar kondisi}

Keterangan :

Garis batas kondisi baseline dan intervensi :

Garis mid date

Garis mid rate

Garis mean level

Garis batas atas

Garis batas bawah

Garis kecendrungan arah

Garis persentase

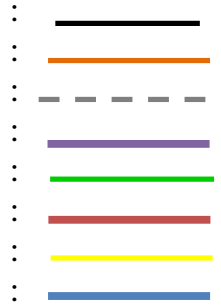

Berdasarkan grafik lebih lanjut akan dijelaskan dalam komponen-komponen antar kondisi. Adapun komponen analisis kondisinya adalah:

a. Menentukan banyak variabel yang diubah

Varibel yang diubah dalam penelitian ini yakni perilaku stereotype (menjilat telapak tangan) siswa autismex.

b. Menentukan Perubahan Kecendrungan Arah

Menentukan perubahan kecenderungan dengan mengambil data pada analisis dalam kondisi, dapat dilihat pada grafik disana terlihat penurunan sehingga pemberian intervensi berpengaruh positif.

c. Menentukan perubahan kecendrungan stabilitas

Menentukannya dengan melihat kecenderungan stabilitas pada masing-masing kondisi. Dapat dikatakan bahwa $\mathrm{A}_{1}$ perkembangan perilaku anak meningkat dari hari pertama sampai hari kelima, pada kondisi B memperlihatkan adanya perubahan kecendrungan data yang menurun, dan pada kondisi $\mathrm{A}_{2}$ perilaku siswa juga menurun saat tidak lagi diberikan intervensi.

d. Menentukan perubahan variabel

Adapun cara menentukan level perubahan pada kondisi baseline sebelum diberikan baseline (A1), pada kondisi intervensi (B), dan pada kondisi baseline tanpa diberikan perlakuan intervensi (A2) dapat diuraikan 
sebagai berikut :

1) Data poin terakhir pada kondisi baseline (A1) adalah 24 frekuensi dan data poin pertama pada kondisi intervensi (B) adalah 16 frekuensi.

2) Data poin pertama baseline tanpa intervensi (A2) adalah 7 frekuensi dan data terakhir pada kondisi ntervensi (B) 7 frekuensi.

\section{e. Menentukan Overlape Data}

Menentukan overlape data pada kondisi baseline sebelum diberikan intervensi (A1) dan intervensi (B) ditentukan dengan cara sebagai berikut :

1) Batas atas $(24,4)$ dan batas bawah $(20,8)$ pada baseline $A_{1}$

2) Kemudian tentukan jumlah data poin pada kondisi intervensi (B) yang berada pada rentang kondisi baseline $\left(\mathrm{A}_{1}\right)$ adalah: 1

3) Overlape $=\frac{1}{10} \times 100 \%=10 \%$

Kemudian menentukan overlap data pada kondisi baseline setelah tidak lagi diberikan intervensi $\left(\mathrm{A}_{2}\right)$ dan intervensi (B) ditentukan dengan cara sebagai berikut :

1) Lihat batas atas dan batas bawah pada kondisi baseline $\left(A_{2}\right)$ yaitu batas bawah 6,125 frekuensi dan batas atas 5,075 frekuensi.

2) Kemudian tentukan jumlah data poin kondisi intervensi (B) yang berada pada rentang kondisi baseline $\left(\mathrm{A}_{2}\right)$

3) Perolehan angka poin dua dibagi banyak data poin yang ada pada kondisi intervensi (B) kemudian dikalikan $100 \% .=0 \%$

\section{Pembahasan}

Teknik aversi telah digunakan secara luas untuk mengurangi atau bahkan menghilangkan gangguan perilaku yang spesifik, melibatkan pengasosiasian tingkah laku simtomatik dengan suatu stimulus yang menyakitkan atau tidak menyenangkan sampai tingkah laku yang tidak diinginkan terhambat kemunculannya, Hadi (2005) Beberapa pendapat ahli diatas peneliti menafsirkan bahwa prosedur aversi merupakan salah satu prosedur yang digunakan untuk mengurangi bahkan menghilangkan perilaku stereotype seseorang dengan menerapkan prinsip pengasosiasian tingkah laku melalui stimulus dan pemberian hukuman. Selanjutnya Bruno (dalam Sodiq, 2005:4) menyatakan, "Perilaku (behavior) adalah segala tindakan yang dilakukan oleh suatu organisme. Pada setiap anak autisme memiliki perilaku yang berbeda. Anak autisme adalah anak yang terditeksi mengalami hambatan dalam perkembangan seperti komunikasi, interaksi dan perilaku. Perilaku yang ditunjukkan oleh kebanyakan anak autisme adalah perilaku stereotype (berulang-ulang).

Berdasarkan analisis data diatas dapat dibuktikan bahwa pengaruh intervensi denganteknik aversi efektif mengurangi perilaku menjilat telapak tangan pada siswa autisme. Dengan diberikannya propmting (brucea javanica) yang dihaluskan dan dioleskan ketelapak tangan siswa, dimana buah ini memiliki rasa yang pahit. Ketika siswa menjilat telapak tangannya maka siswa akan merasakan kepahitan buah tersebut dan perilakunya berkurang sehingga kutu air disela-sela jari hilang. Jadi jelas bahwa dengan menggunakan teknik Aversi dapat mengurangi perilaku stereotype menjilat telapak tangan pada siswa autisme $\mathrm{X}$.

\section{Kesimpulan}

Pengamatan yang dilakukan sebanyak 20 kali, lima kali pengamatan kondisi baseline $\left(\mathrm{A}_{1}\right)$, dan terlihat perilaku menjilat telapak tangan siswa meningkat. Pada kondisi intervensi (B) anak diberikan perlakuan dengan menggunakan teknik aversi sebanyak sepuluh kali pengamatan dan hasilnya perilaku stereotype menjilat telapak tangan siswa berkurang. Kemudian diberikan pengamatan kembali, yaitu kondisi baseline $\left(\mathrm{A}_{2}\right)$, kondisi dimana tidak diberikan perlakuan. Pada pengamatan ini dilakukan sebanyak lima kali dengan hasil perilaku stereotype siswa berkurang. Berdasarkan hal tersebut, maka dapat dinyatakan bahwa perilaku berlebihan menjilat telapak tangan siswa autisme $\mathrm{X}$ dapat dikurangi melalui teknik aversi

\section{Daftar Rujukan}

Hadi, Purwaka. (2005). Modifikasi Perilaku. Jakarta: Departemen Pendidikan Nasional.

Syaodih, N., \& Sukmadinata. (2007). Metode Penelitian Pendidikan. Bandung: Remaja Rosdakarya.

Sunanto, Juang. (2005). Pengantar Penelitian dengan Subjek Tunggal. Bandung: UNP Press. 